\title{
Article \\ Effects of a Wave Power Park with No-Take Zone on Decapod Abundance and Size
}

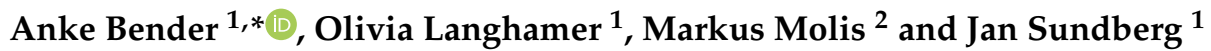 \\ 1 Division of Electricity, Uppsala University, P.O. Box 534, 75121 Uppsala, Sweden; \\ olanghamer@gmail.com (O.L.); jan.sundberg@angstrom.uu.se (J.S.) \\ 2 Institute of Arctic and Marine Biology, UiT The Arctic University of Norway, P.O. Box 6050 Langnes, \\ 9037 Tromsø, Norway; markus.molis@uit.no \\ * Correspondence: anke.bender@angstrom.uu.se; Tel.: +46-70027-8905
}

\section{check for} updates

Citation: Bender, A.; Langhamer, O.; Molis, M.; Sundberg, J. Effects of a Wave Power Park with No-Take Zone on Decapod Abundance and Size. J. Mar. Sci. Eng. 2021, 9, 864. https:// doi.org/10.3390/jmse9080864

Received: 12 July 2021

Accepted: 6 August 2021

Published: 11 August 2021

Publisher's Note: MDPI stays neutral with regard to jurisdictional claims in published maps and institutional affiliations.

Copyright: (c) 2021 by the authors. Licensee MDPI, Basel, Switzerland. This article is an open access article distributed under the terms and conditions of the Creative Commons Attribution (CC BY) license (https:// creativecommons.org/licenses/by/ $4.0 /)$.

\begin{abstract}
Past studies have revealed higher levels of biodiversity, total abundance, and size of individuals around offshore installations of renewable energy. This study investigated the effects of Lysekil wave power park (area $0.5 \mathrm{~km}^{2}$ ) on the abundance and carapace size of decapods at the Swedish west coast. For that purpose, decapods were caught with cages during four consecutive summers. Two types of cages were applied to catch a wide range of decapod species and sizes. The abundance and size of decapods were not significantly different within the wave power park and up to a distance of $360 \mathrm{~m}$ outside of it. The catch rate, i.e., number of decapods caught in $24 \mathrm{~h}$, was not significantly different among sampling locations but revealed inter-annual variation for both cage types. The results suggest a limited role of the incidental no-take zone of the small Lysekil wave power park on the abundance and size of local decapods. However, neither were negative impacts, such as decreasing abundances or smaller carapace sizes, discovered. As an increase in the number of marine renewable energy production sites is foreseen, a scaled-up and larger study addressing MPA networks and other environmental interactions should be considered.
\end{abstract}

Keywords: marine renewable energy; wave energy; marine protected area (MPA); no-take zone; co-location; environmental effects; mid-term study

\section{Introduction}

One of the 17 sustainable development goals of the United Nations, planned to be realized by 2030, is to achieve affordable and sustainable energy (Goal 7). Its objective is to substantially increase the share of renewable energy in the global energy mix [1]. The number of offshore renewable energy (ORE) projects, such as offshore wind farms, as well as wave and tidal energy projects, has been growing in the past few years [2,3]. ORE projects can contribute substantially to reaching Goal 7. The transition to including more renewable energy sources needs to be accomplished in a sustainable way. Energy generation, including ORE projects, can affect the environment [4]. As relatively new technologies, it is important to investigate environmental effects of ORE installations early in order to have the chance to mitigate eventual negative impacts.

During the different stages of an ORE project (deployment, operation, decommissioning), the degree of physical disturbance varies, and this variation is further dependent on the technology of the applied device and way of deployment [5]. Direct effects of ORE installations on the coastal environment include, inter alia, enhanced water turbidity [6], changes of hydrodynamics [6], noise emission [7], electromagnetic fields [3], and risk of collision or entanglement [8]. Some of the influences are specific to the construction and decommissioning phase such as increased turbidity, noise, and vibrations. Other perturbations mainly occur during the operational phase, such as the generation of electromagnetic fields, and the risk of collision and entanglement. Indirect ecological effects of ORE installations can occur as a result of temporal and spatial shifts in species distribution of 
mobile fauna, with consequent changes in food-web dynamics, predator-prey relationships, species reproduction, and recruitment [5].

However, there is also empirical evidence of the ecological benefits of installed OREs. The structures represent, for instance, an additional colonization substratum for benthic biota $[5,9]$. ORE devices are primarily deployed in soft-bottom environments, where space for the colonization of sessile hard-bottom species such as filter-feeding mussels is a limiting resource [6]. The physical structure of an ORE device can locally increase the heterogeneity of benthic habitats. The resulting artificial reef effect by the introduced structures can increase species richness and the density of mobile and sessile organisms [10-15]. Fast colonization of the structures by sessile organisms is commonly observed [14,16], but the attraction of pelagic and demersal fish and increased densities of decapods and mega-fauna were also found [17-19]. Because of the species- and biomass-rich communities that live attached to and associated with ORE devices, the adjacent soft-bottom area may be locally enriched through deposition of organic material and can thereby positively influence densities of benthic epi- and infauna, which in turn serve as food sources for higher trophic levels $[20,21]$. The locally enriched epi- and infauna provide additional nutrition and might contribute to the growth of decapods of larger size.

Another positive indirect effect of ORE devices includes the generation of incidental no-take zones that arises from the presence of the new infrastructure [22]. Many ORE parks prohibit human activities such as fishing and marine traffic, with potentially similar beneficial effects on biodiversity like marine protected areas (MPA) or intended no-take zones. The term MPA refers to marine areas where human activities have been restricted with the aim of protecting living and non-living resources [4]. MPAs are known to provide several advantages for the biota living inside a protected area [23-27]. The influences from this approach bear benefits for multiple species and ecosystems, as well as general effects such as the recovery of benthic areas from invasive fishing and overfishing in general.

The strength of protection may vary, with a no-take zone being the strongest level of protection, followed by spatial and temporal variations in protection and exceptions [28]. The size of an MPA can play an important factor in the protection success. Whereas moderately sized MPAs (i.e., 4-20 km²) are important to conserving biodiversity or supporting climate change resilience, smaller sized MPAs (i.e., $0.5-1 \mathrm{~km}^{2}$ ) can increase the abundance and biomass of species, and several examples of small, effective MPAs exist [24,29-34].

The benefits of MPAs have proven to increase the size, biodiversity, density, body mass, and reproductive potential of many species as a direct result of protection $[23,26,34,35]$. The spiny lobster (Jasus edwarsii) increased by $22 \%$ in mean abundance and up to $28 \mathrm{~mm}$ in carapace length five years after the establishment of a reserve [36]. The catch rate of spiny lobster (Palinurus elephas) was 7.5 times greater inside the protected area than in the adjacent, unprotected zone [30]. Several studies showed that the number and size of individuals of benthic biota increased inside an MPA compared to outside. Empirical evidence exists about the declining number and size of individuals of benthic biota within the first $1000 \mathrm{~m}$ outside MPAs [25,36-41]. Adjacent zones and fisheries can profit from MPAs, too. Benefits are expected from the recruitment of exported eggs and larvae as well as from spillover of adults to adjacent fishing grounds. This effect has been shown in several studies [36,42]. ORE parks could principally function as MPAs. In a study northwest of Great Britain, for instance, more and larger European lobsters were found inside a wind farm park where fishing was temporarily excluded than outside [43]. One idea to reduce conflicts between ocean use and conservation needs is to relax competing demands on marine space by co-location of ORE installations with marine protected areas $[4,6,44-46]$.

Our studies were performed at the resting Lysekil wave power park on the west coast of Sweden [47,48]. Marine activities such as boat traffic or fishing are restricted inside the park area. Past environmental studies from the Lysekil research site showed an increased biomass, diversity, and abundance of epifauna and infauna on the wave power foundations as well as one meter around, representing an additional potential food source for decapods, $[13,14]$. The aim of this study was to investigate the possible effects of 
the incidental no-take zone created by the presence of the wave power park on decapod abundance and carapace size. We quantified decapod abundance and carapace size on a larger range in the park and outside of the park by deploying cages in the park and up to $360 \mathrm{~m}$ outside. We expected to find more individuals of decapods and with larger carapace sizes within and closer to than further away from the park due to the benefits of the no-take zone.

\section{Materials and Methods}

\subsection{Study Area}

The Lysekil research site is located ca. $2 \mathrm{~km}$ off the Swedish west coast near the Islandsberg lighthouse. The site is marked at the northern and southern boundaries with a sea marking (northern marking $58^{\circ} 11^{\prime} 850 \mathrm{~N} ; 1^{\circ} 22^{\prime} 460 \mathrm{E}$ and southern marking $58^{\circ} 11^{\prime} 630 \mathrm{~N}$; $11^{\circ} 22^{\prime} 460$ E) (Figure 1A) and covers an area of around $0.5 \mathrm{~km}^{2}$ [49]. The seafloor at the research site is at a depth of $25 \mathrm{~m}$, consists of sand, and shows little relief [50]. On the western coast of Sweden, winds and waves come predominantly from westerly directions. The tidal range at Lysekil is ca. $0.3 \mathrm{~m} \mathrm{[51]} \mathrm{and} \mathrm{average} \mathrm{salinity} \mathrm{in} \mathrm{the} \mathrm{area} \mathrm{is} \mathrm{approximately} 25 \%$ [52].

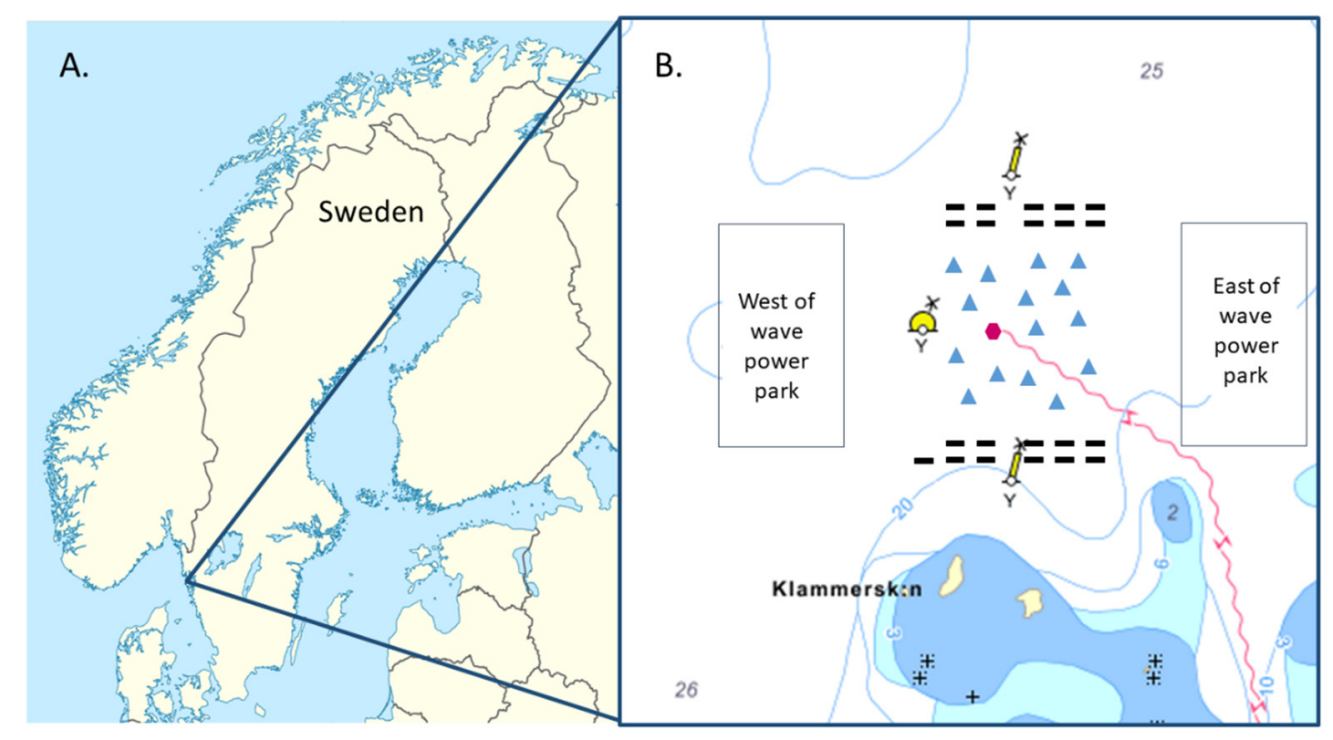

Figure 1. (A) Location of the Lysekil research site on the Swedish west coast. (B) Sea chart of the wave power park, marked with two yellow rod-shaped sea markings. The yellow buoy between the two rod-shaped sea markings indicates the position of the wave-measuring buoy. The red line indicates the position of a sea cable. Blue triangles mark the position of generators, black rectangles mark ecological foundations, and the red hexagon indicates the position of the marine substation. Sampling locations east and west of the wave power park are marked as squares. Numbers indicate water depth and light-yellow areas represent islands. Note: size and position of symbols are not to scale.

A heaving point-absorber wave power generator was developed by Uppsala University [48]. The first full-scale generator was deployed in 2006 at the Lysekil research site, followed by further deployments in the following years [48]. Throughout this study, wave power generators were neither connected to wave buoys nor was electricity generated, and thus, the park can be referred to as resting. In 2007, 21 concrete cylinders of $1 \mathrm{~m}$ height, $3 \mathrm{~m}$ diameter, and with a weight of 10 tons each (hereafter referred to as "ecological foundations") were deployed in the Lysekil research site (Figure 2). Ecological foundations were used to simulate foundations of wave generators and to conduct studies on their environmental and ecological impact. Fishing and other activities have been undesired in the research area since 2006, yet violations to that occurred throughout all study years 
(personal observation). However, recreational cage fishing for decapods and boat traffic takes place in the area around the park.

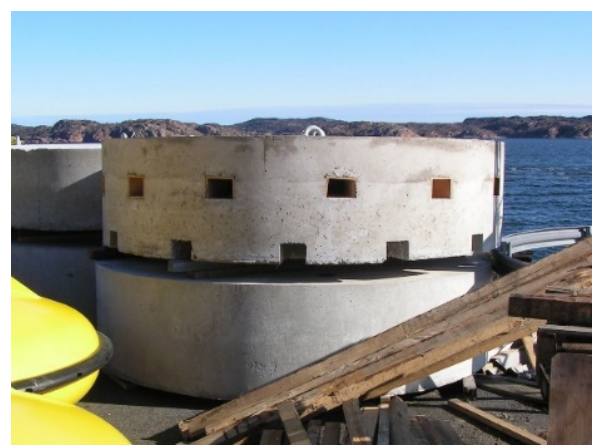

Figure 2. Two ecological foundations for environmental and ecological studies in the Lysekil wave power park research site. Upper ecological foundations include manufactured holes for increased complexity.

\subsection{Experimental Design and Cage Types}

The cages were deployed between June 25 and July 24 in the years 2016 to 2019 to ensure comparable environmental conditions among years. Two different cage types (Figure $3 a, b$ ) were used for the study to catch a wide range of species and sizes of the local decapod community. Both cage types are commonly used for commercial and recreational fishing. Each deployed cage was baited with half a salted herring before its $24 \mathrm{~h}$ deployment. The deployment of the cages took place inside the wave power park as well as to the east and west outside of it (Figure 1B). During the deployment, the GPS position of each cage was taken and its distance to the closest ecological foundation was calculated. The carapace width of all captured decapods was measured. Subsequently, each individual was tagged with a t-bar anchor to identify potential recatches, and all individuals were returned to the respective sampling location. Every year, cages were placed at approximately similar positions.

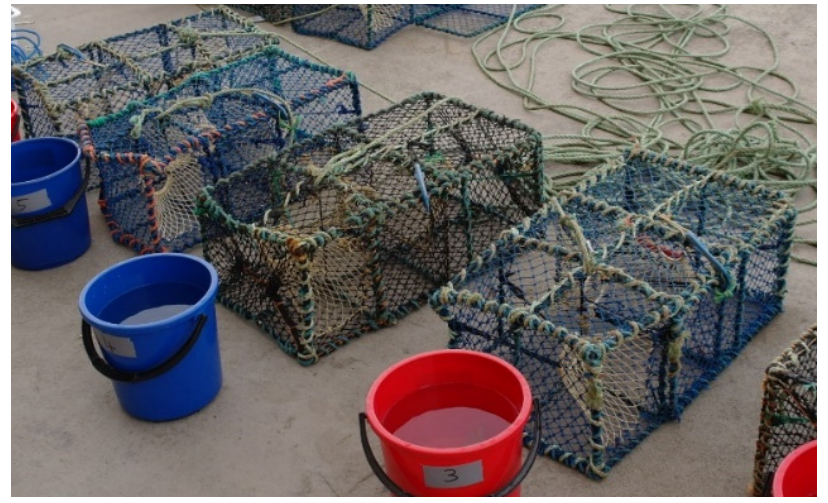

(a)

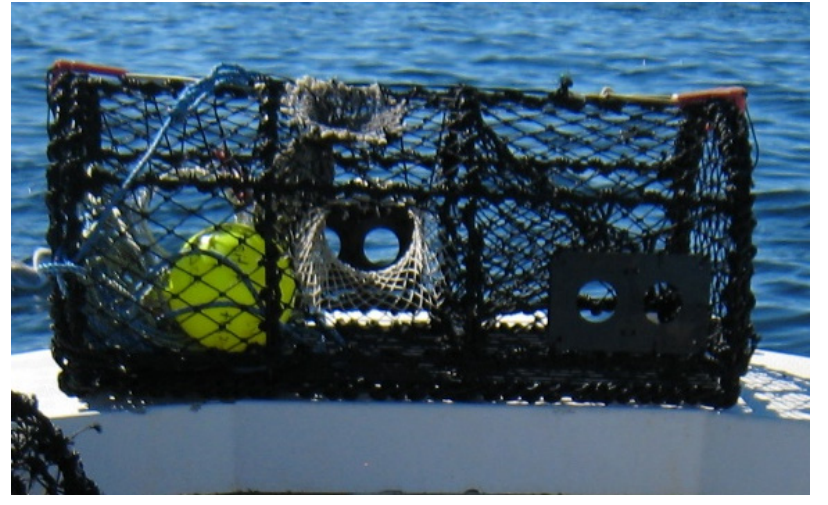

(b)

Figure 3. (a) Small cage type, with two entrances one on each long side (white funnel-shaped net); (b) lateral view of large cage type, with two entrances, one on each long side (white funnel-shaped net). The yellow surface buoy and line are stored in the left chamber of the cage.

\subsubsection{Small Cage Type}

The small cage type $(70 \mathrm{~cm}$ length, $40 \mathrm{~cm}$ width, $28 \mathrm{~cm}$ height), with a mesh size of $22 \mathrm{~mm} \times 22 \mathrm{~mm}$, has two entrances ( $7 \mathrm{~cm}$ diameter), one on each long side (Figure 3a). This cage type is used in commercial fishing to fish for Norway lobster (Nephrops norvegicus). Six cages were connected with a line (hereafter "cage line") and a total of three cage lines were 
used simultaneously with one cage line inside the park, one east and one west of the park. In 2018, the three cage lines were deployed three times due to optimal weather conditions (Table 1). The distance between adjacent cages on a line was approximately $10 \mathrm{~m}$. At each end of the line, an anchor weight and a line with a surface buoy was connected for retrieval. Distances from the cages to the ecological foundations ranged between $35 \mathrm{~m}$ and $275 \mathrm{~m}$.

Table 1. Number of deployed small and large cages and rounds of deployments throughout the sampling period of different years at the three sampling locations.

\begin{tabular}{ccccc}
\hline Deployed Cages & West of Park & Inside Park & East of Park & Total Cages \\
\hline Small 2016 & 6 & 6 & 6 & 18 \\
Small 2017 & 6 & 6 & 6 & 18 \\
Small 2018 & $3 \times 6$ & $3 \times 6$ & $3 \times 6$ & 54 \\
Total small cages & 30 & 30 & 30 & 90 \\
\hline Large 2016 & $1 \times 6 / 1 \times 5$ & $1 \times 6 / 1 \times 5$ & $2 \times 5$ & 32 \\
Large 2017 & $2 \times 6$ & $2 \times 6$ & $2 \times 6$ & 36 \\
Large 2018 & $2 \times 6$ & $2 \times 6$ & $2 \times 6 / 1 \times 5$ & 41 \\
Large 2019 & $3 \times 7$ & $3 \times 7$ & $3 \times 7$ & 63 \\
Total large cages & 56 & 56 & 60 & 172 \\
\hline
\end{tabular}

\subsubsection{Large Cage Type}

The large cage type (92 cm length, $46 \mathrm{~cm}$ width, $38 \mathrm{~cm}$ height), with a mesh size of $30 \mathrm{~mm} \times 30 \mathrm{~mm}$, has two entrances, one at the center of each long side with a diameter of $12 \mathrm{~cm}$ (Figure $3 \mathrm{~b}$ ). This cage type is used in commercial and recreational fishing to catch European lobster (Homarus gammarus) and brown crab (Cancer pagurus). Each cage contained a line with a surface buoy to retrieve the cage. Five to 7 cages were simultaneously deployed at one sampling location. This range resulted from a loss of one cage, its replacement, and the regain of the lost cage throughout the study years. Each year, several deployments with 5-7 cages were conducted over the study period (Table 1). Distances to the ecological foundations ranged between $2 \mathrm{~m}$ and $362 \mathrm{~m}$.

\subsection{Statistical Analyses}

All analyses were conducted using statistical software R (version 3.5.1, Vienna, Austria), enabled via RStudio (version 1.1.463, Vienna, Austria) [53].

\subsubsection{Catch Rate}

Differences in the catch rate, i.e., the number of decapods caught in a $24 \mathrm{~h}$ deployment period, among (i) years and (ii) sampling locations were evaluated using one-way analysis of variance (ANOVA) with the "aov" function of the $\mathrm{R}$ "base" package v 3.5.1 [53]. The analysis was performed independently for both cage types. ANOVAs comparing catch rates among years grouped all cages deployed in a given year, regardless of the location of deployment, resulting in 3 and 4 fixed levels for ANOVAs in small and large cages, respectively. Comparisons between sampling locations (fixed, three levels: inside the wave power park, and east and west of the wave power park) were run for each year and type of cage separately (i.e., a total of 7 ANOVAs). The inverse value of variance was included in the ANOVA to account for weighting unequal numbers of cages among years and sampling locations for the large cage type, and among years for the small cage type. A Tukey post hoc test ( $\mathrm{R}$ base, v 3.5.1, function: "TukeyHSD") [53] was performed to reveal differences among factor levels in case of significant difference (i.e., $\alpha$ set to $\leq 0.05$ ). Homogeneity of variances was confirmed with plots of residuals vs. fitted values. We used quantile-quantile plots (R base, v 3.5.1, function: "qqnorm") [53] as well as the Kolmogorov-Smirnov test (R base, v 3.5.1, function: "ks.test") [54] to test whether the data were normally distributed. Violation of normality occurred for the catch rate data among the years for the large cage type and for the catch rate data among the sampling locations for the small cage type. For these comparisons, a Kruskal-Wallis test with the "kruskal.test" function of the R "base" 
package v 3.5.1 [53] was performed as a non-parametric alternative. In case of significant difference, pairwise Mann-Whitney U tests (R base, v 3.5.1, function: "wilcox.test") [53] were carried out to detect differences between factor levels.

\subsubsection{Number of Decapods and Carapace Width}

A linear model (R base v 3.5.1, function: " $1 \mathrm{~m}$ ") [53] was used to fit the number of decapods per cage as a function of distance to the closest ecological foundation for both cage types independently, either for each year separately or combined for all years. The carapace width for the three most abundant species, Cancer pagurus, Carcinus maenas, and Liocarcinus depurator, was analyzed independently for each cage type but combined for all years to unmask differences due to size differences in the species. A linear model was used to fit the average carapace width for each of the three species per cage as a function of distance to the closest ecological foundation.

Homogeneity of variances was confirmed with plots of residuals and standardized residuals vs. fitted values. We tested for outliers using Cook's distance plot and no outliers were found. We used quantile-quantile plots (R base, v 3.5.1, function: "qqnorm") as well as the Kolmogorov-Smirnov test (R base, v 3.5.1, function: "ks.test") [52] to test whether the data were normally distributed. Model residuals were not normally distributed for the data of the decapod abundance caught with the small and large cages for all years combined or in the years 2018, 2019 for the data of decapod abundance caught with the large cages, despite attempts to $\log (1+\mathrm{x})$-transform the response variable. However, linear and linear mixed effects models are quite robust to violation of assumptions regarding normality of model residuals [54-56].

\section{Results}

Five decapod species were caught throughout the years with large and small cages: brown crab (Cancer pagurus), shore crab (Carcinus maenas), sandy swimming crab (Liocarcinus depurator), great spider crab (Hyas araneus), and common hermit crab (Pagurus bernhardus). For three species, the hermit crab (Pagurus pubescens), a squat lobster species (Galathea spp.), and the European lobster (Homarus gammarus), we encountered only a single individual during the entire study (Table 2). Over the entire study period, 19 small cages $(21 \%)$ and 21 large cages (12\%) remained empty (Table 2). All catches comprised exclusively native species.

Table 2. Number of individuals of decapod species caught during all sampling years in small cages (90 cages total) and large cages (172 cages total).

\begin{tabular}{ccc}
\hline Species & $\begin{array}{c}\text { Individuals } \\
\text { Small Cages }\end{array}$ & $\begin{array}{c}\text { Individuals } \\
\text { Large Cages }\end{array}$ \\
\hline Cancer pagurus & 38 & 165 \\
Carcinus maenas & 92 & 45 \\
Liocarcinus depurator & 102 & 63 \\
Hyas araneus & 8 & 10 \\
Pagurus pubescens & 1 & 0 \\
Pagurus bernhardus & 1 & 6 \\
Homarus gammarus & 0 & 1 \\
Galathea spp. & 1 & 0 \\
\hline Total number of decapods & 243 & 290 \\
Total number of cages & 90 & 172 \\
Total empty cages & 19 & 21 \\
\hline
\end{tabular}

\subsection{Catch Rate}

\subsubsection{Catch Rate of Decapods with Small Cages}

Decapod catch rate was significantly different among years (Kruskal-Wallis test: chi-square $=45.22, p<0.001)$. We captured, on average, 3.9 and 2.7 times more decapods in 
2016 and 2017, respectively, than in 2018 (Figure 4a). The catch rate in 2017 was, on average, $24 \%$ lower than in 2016, and they were not significantly different from each other. Decapod catch rates were not significantly different among sampling locations.

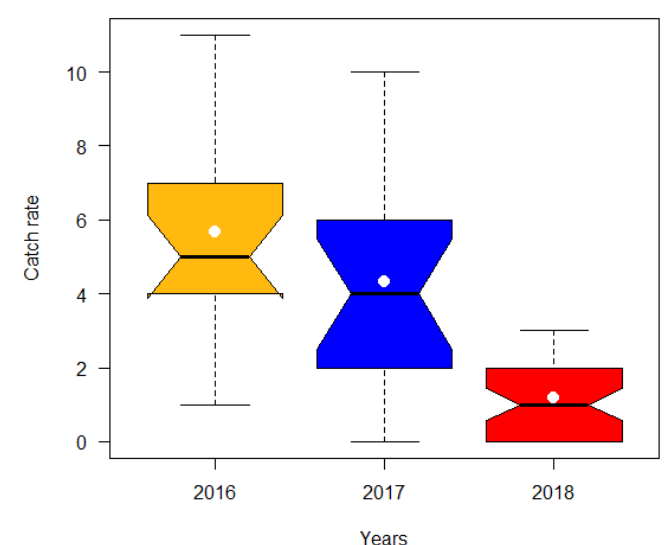

(a)

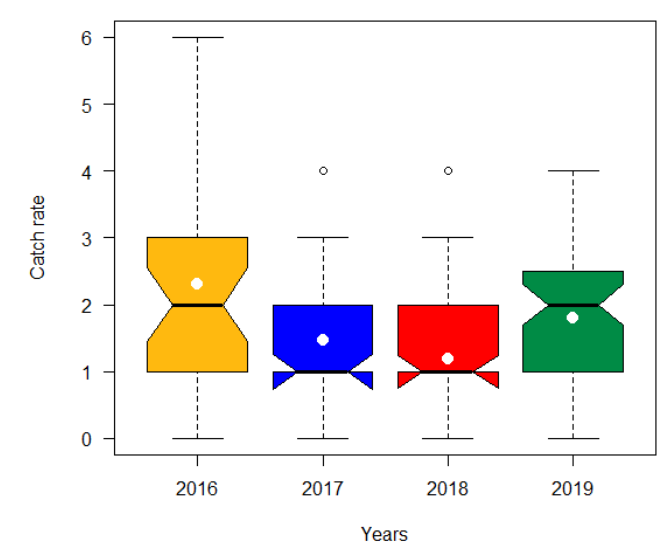

(b)

Figure 4. Mean catch rate (white dot), i.e., number of decapods caught in a $24 \mathrm{~h}$ deployment period, with 25 and $75 \%$ quartiles (lower and upper box margin, respectively) and 95\% confidence interval (whisker), median (thick black bar), notch (95\% confidence interval of the median), and possible outliers (open dots) among the different survey years for (a) small and (b) large cages.

\subsubsection{Catch Rate of Decapods with Large Cages}

Decapod catch rate was significantly different among years (1-way ANOVA: $F(3,168)=6.79, p<0.001)$. There were, on average, 1.6 and 1.2 times more decapods encountered in cages in 2016 and 2019, respectively, than in 2017, and on average, 1.9 and 1.5 times more decapods encountered in cages in 2016 and 2019, respectively, than in 2018 (Figure $4 \mathrm{~b}$ ). The difference in catch rate of 22\% between 2016 and 2019 and the difference in catch rate of 19\% between 2017 and 2018 were statistically not significantly different. Decapod catch rates were not significantly different among sampling locations.

\subsection{Number of Decapods \\ 3.2.1. Small Cages}

The mean number of decapods per cage, including all years and sampling sites, was 2.7 individuals and the range of caught decapods per cage was 1-11 (Figure 5). When the data of different years were pooled, the number of decapods caught with small cages increased with distance to the ecological foundations, on average, by 0.1 individuals every $100 \mathrm{~m}$ (linear model: abundance $=0.001 \times$ Distance $(D)+2.57$ (Figure 5)), indicating a statistically non-significant relationship between decapod abundance and distance to the ecological foundations $(F(1,88)=0.007, p=0.79)$. Variation in decapod abundance was large and is also reflected by a low level of explained data variance $\left(r^{2}=0.08 \%\right)$ by the model.

When data were analyzed for each year separately, the number of captured decapods increased every $100 \mathrm{~m}$ away from the wave power park by 0.7 individuals in 2016, and decreased by 0.1 individuals in 2018. For 2017, linear regression analyses suggest a statistically significant relationship between decapod abundance and distance to the ecological foundations $(\mathrm{F}(1,16)=10.29, p=0.006)$ (Table 3$)$. The number of decapods in the year 2017 increased, on average, by 2.9 individuals for every $100 \mathrm{~m}$ away from the ecological foundations (linear model: abundance $=0.029 \times 100+0.86$ ) (Figure 5). 


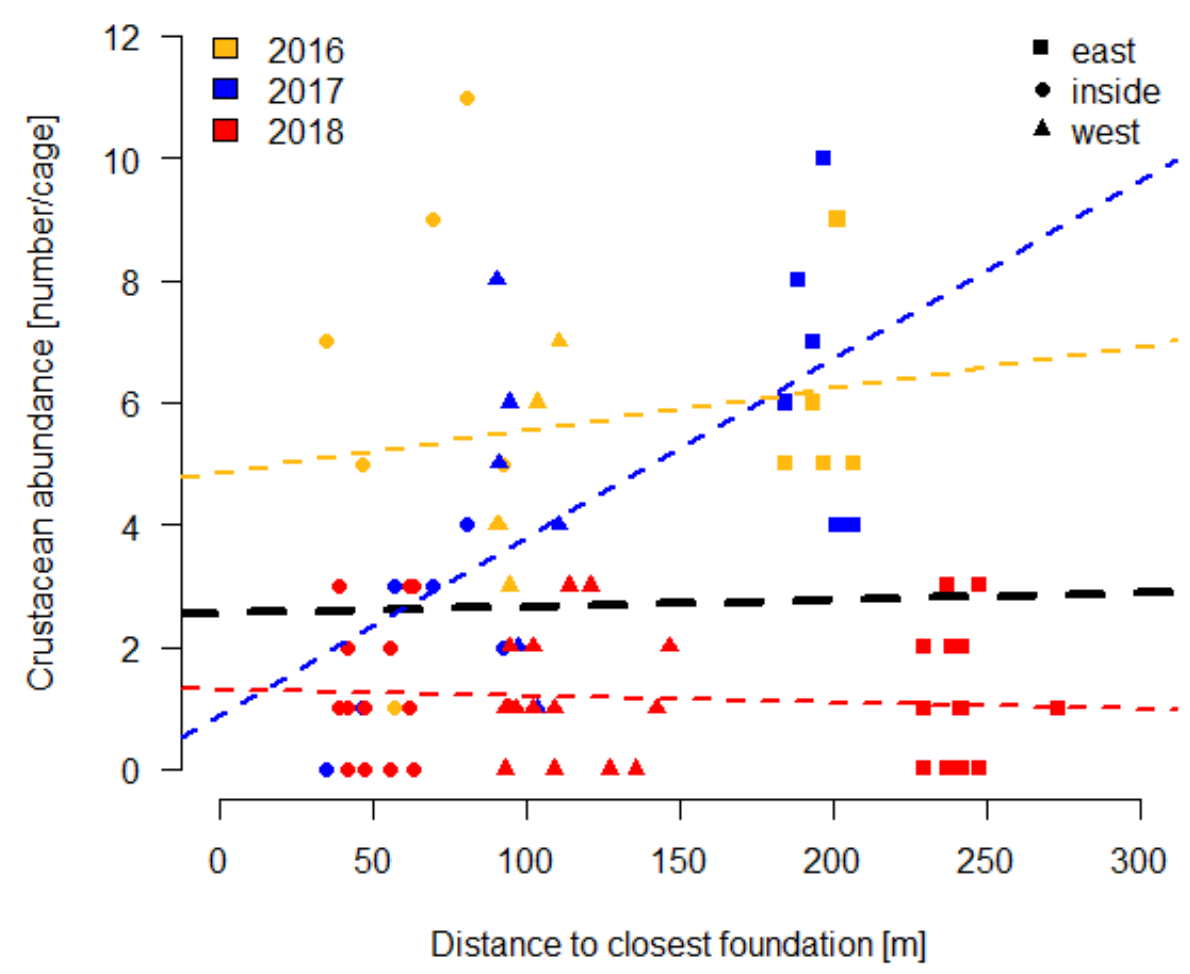

Figure 5. Number of decapods captured with small cages in 2016-2018. Black dashed line represents pooled regression line of all years. Single years are represented by dashed lines in colors according to years in the legend.

Table 3. Results of the linear models with number of decapods per cage as a function of distance to the closest ecological foundation (=D) for the different combinations of cage type and year.

\begin{tabular}{cccccc}
\hline Cages & Number of Cages & F-Statistic & $\mathbf{r}^{\mathbf{2}}$ & $\boldsymbol{p}$-Value & Linear Model: Abundance \\
\hline Small 2016 & 18 & 0.42 & 0.03 & 0.528 & $0.007 \times \mathrm{D}+4.85$ \\
Small 2017 & 18 & 10.29 & 0.391 & 0.006 & $0.029 \times \mathrm{D}+0.86$ \\
Small 2018 & 54 & 0.38 & 0.007 & 0.538 & $-0.001 \times \mathrm{D}+1.31$ \\
Small pooled & 90 & 0.007 & 0.0008 & 0.79 & $0.001 \times \mathrm{D}+2.57$ \\
\hline Large 2016 & 32 & 0.87 & 0.03 & 0.359 & $0.002 \times \mathrm{D}+2.04$ \\
Large 2017 & 36 & 0.50 & 0.015 & 0.482 & $0.001 \times \mathrm{D}+1.29$ \\
Large 2018 & 41 & 1.01 & 0.03 & 0.321 & $-0.002 \times \mathrm{D}+1.45$ \\
Large 2019 & 63 & 0.01 & 0.0001 & 0.931 & $0.0001 \times \mathrm{D}+1.71$ \\
Large pooled & 172 & 0.06 & 0.0004 & 0.81 & $-0.0002 \times \mathrm{D}+1.69$ \\
\hline
\end{tabular}

\subsubsection{Large Cages}

The mean number of decapods per cage, including all years and sampling sites, was 1.7 individuals and the range of caught decapods per cage and calculated distance was 1-6 individuals (Figure 6). The number of decapods decreased, on average, by 0.02 individuals every $100 \mathrm{~m}$ (linear model: abundance $=-0.0002 \times \mathrm{D}+1.69$ ) (Figure 6), indicating a non-significant relationship between decapod abundance and distance to the ecological foundations $(\mathrm{F}(1,170)=0.06, p=0.81)$. Variation in decapod abundance was relatively large and is also reflected by a low level of explained data variance $\left(r^{2}=0.04 \%\right)$ by the model. Linear regression of single years indicated a non-significant relationship between decapod abundance and distance to the ecological foundations (Figure 6 and Table 3). When data were analyzed for each year separately, the number of captured decapods increased every $100 \mathrm{~m}$ away from the wave power park by $0.2,0.1$, and 0.01 individuals in 2016, 2017, and 2019, respectively. In the year 2018, the number of captured decapods decreased every $100 \mathrm{~m}$ away from the wave power park by 0.2 individuals. In no case did 
the relationship between decapod abundance and distance to the ecological foundations indicate a statistically significant relationship.

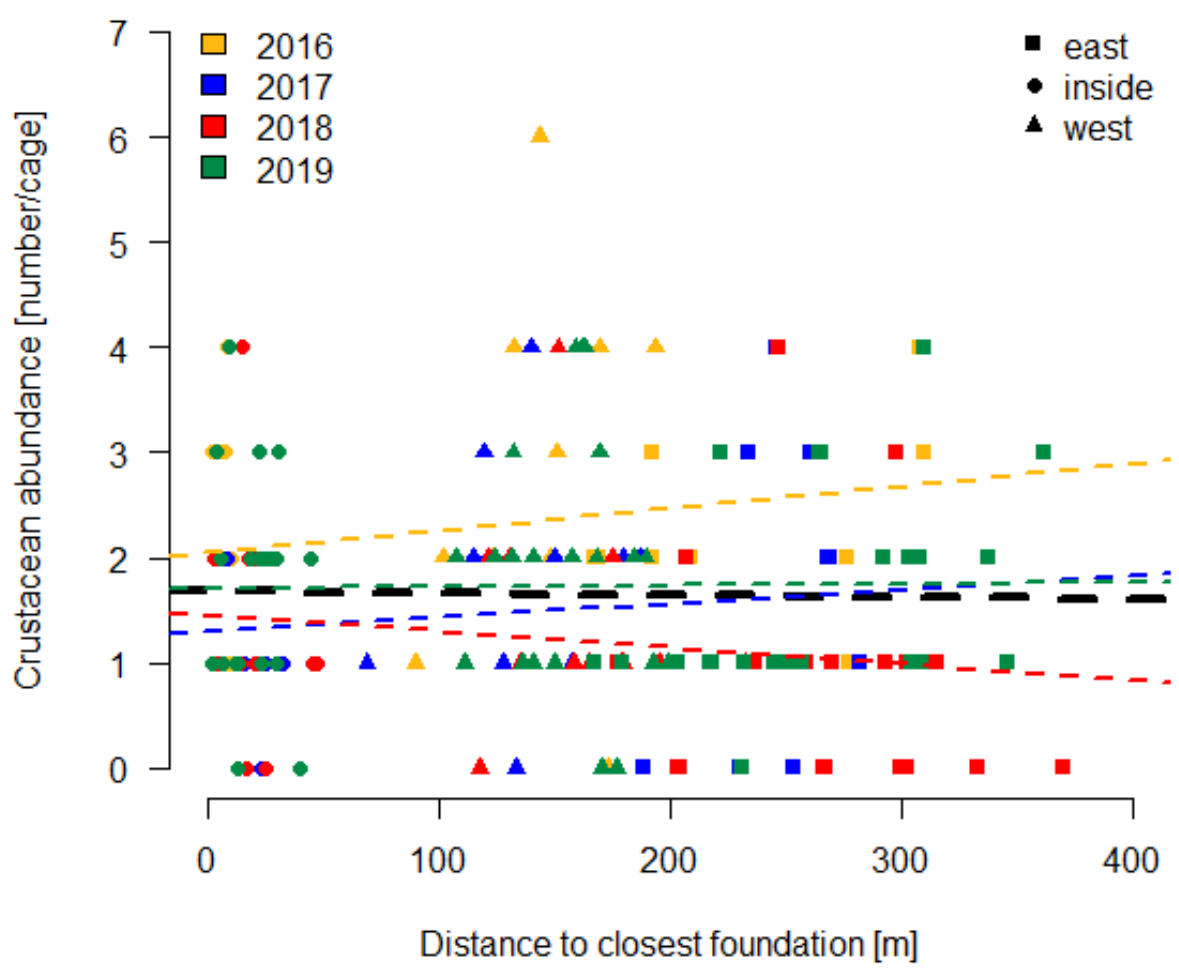

Figure 6. Number of decapods captured with the large cages in 2016-2019. Black dashed line represents pooled regression line of all years. Single years are represented by dashed lines in colors according to years in the legend.

\subsection{Carapace Width}

Cancer pagurus, Carcinus maenas, and Liocarcinus depurator caught with the small and large cages indicated a non-significant relationship between carapace width and distance to the ecological foundations (Figures 7a-c and 8b,c and Table 4), with one exception of Cancer pagurus caught with the large cages (Figure 8a and Table 4). The carapace width of Cancer pagurus decreased, on average, by $0.45 \mathrm{~cm}$ every $100 \mathrm{~m}$ (linear model: abundance $=-0.0045$ $\times \mathrm{D}+13.33$ ) (Figure 8a), indicating a significant relationship between brown crab carapace width and distance to the ecological foundations in $2017(\mathrm{~F}(1,115)=4.47, p=0.037)$.

Table 4. Results of the linear models with carapace width of the three most abundant decapod species as a function of distance to the closest ecological foundation (=D) for the two cage types.

\begin{tabular}{cccccc}
\hline Small Cages & Number of Cages & F-Statistic & $\mathbf{r}^{\mathbf{2}}$ & $\boldsymbol{p}$-Value & Linear Model: Carapace Width \\
\hline $\begin{array}{c}\text { Cancer pagurus } \\
\begin{array}{c}\text { Carcinus maenas } \\
\text { Liocarcinus }\end{array}\end{array}$ & 32 & 0.04 & 0.001 & 0.849 & $-0.0006 \times \mathrm{D}+9.91$ \\
$\quad 28$ & 2.13 & 0.076 & 0.157 & $0.0021 \times \mathrm{D}+6.16$ \\
\hline depurator & 52 & 0.06 & 0.001 & 0.802 & $-0.0002 \times \mathrm{D}+5.17$ \\
\hline Large Cages & Number of Cages & F-Statistic & $\mathbf{r}^{2}$ & $\boldsymbol{p}$-Value & Linear Model: Carapace Width \\
\hline $\begin{array}{c}\text { Cancer pagurus } \\
\text { Carcinus maenas } \\
\text { Liocarcinus }\end{array}$ & 117 & 4.47 & 0.037 & 0.037 & $-0.0045 \times \mathrm{D}+13.33$ \\
$\quad$ depurator & 27 & 2.61 & 0.095 & 0.058 & $-0.0026 \times \mathrm{D}+6.86$ \\
& 45 & 0.16 & 0.004 & 0.693 & $-0.0007 \times \mathrm{D}+5.32$ \\
\hline
\end{tabular}




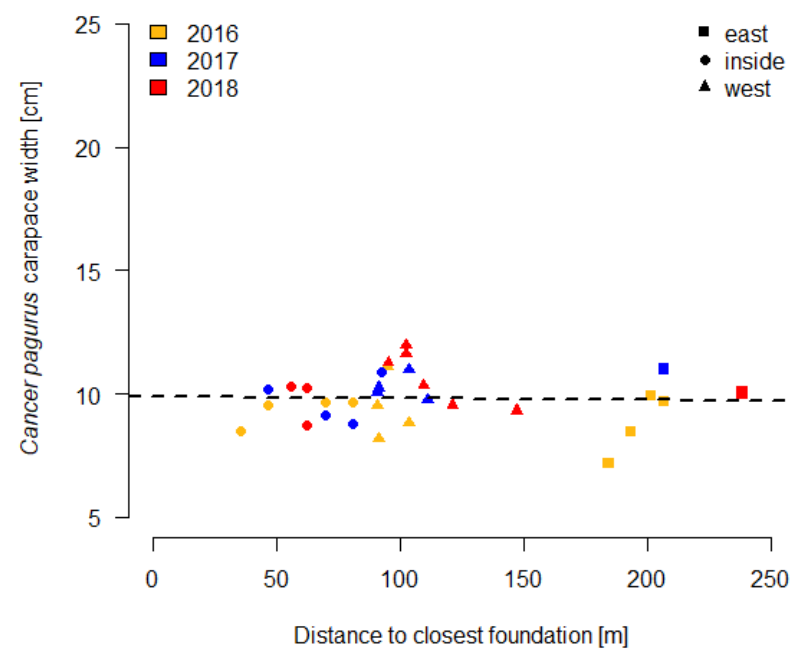

(a)

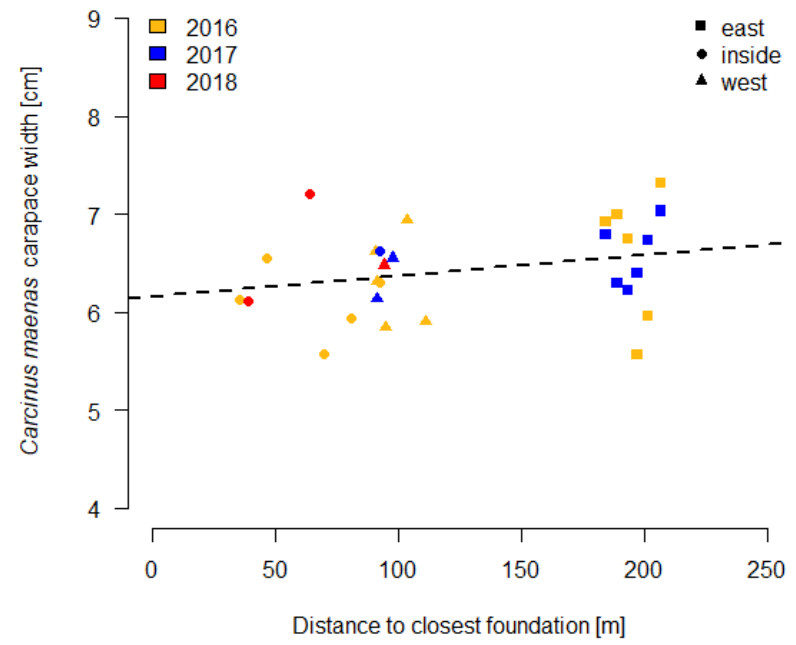

(b)

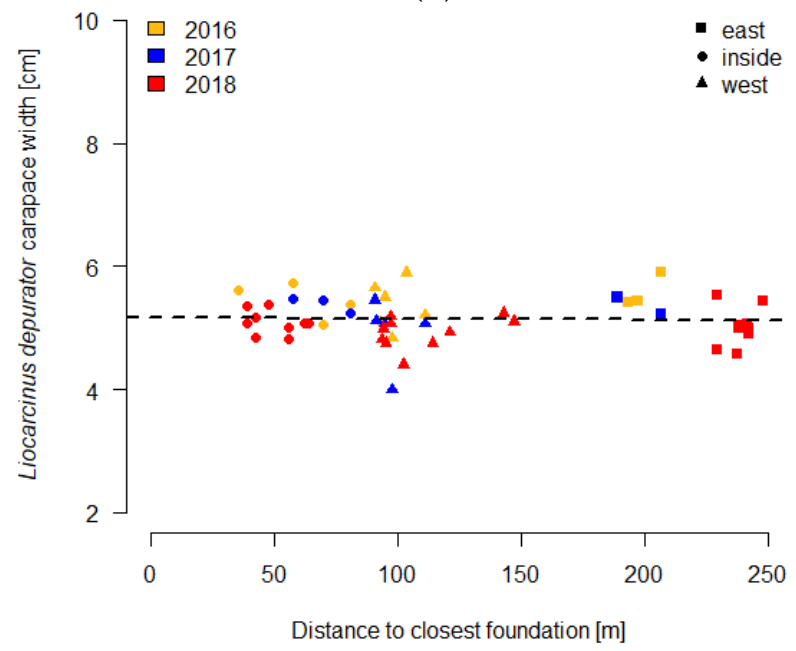

(c)

Figure 7. Average carapace width per decapod species: (a) Cancer pagurus, (b) Carcinus maenas, and (c) Liocarcinus depurator captured with small cages in 2016-2018. Black dashed line represents a pooled regression line for all years. 


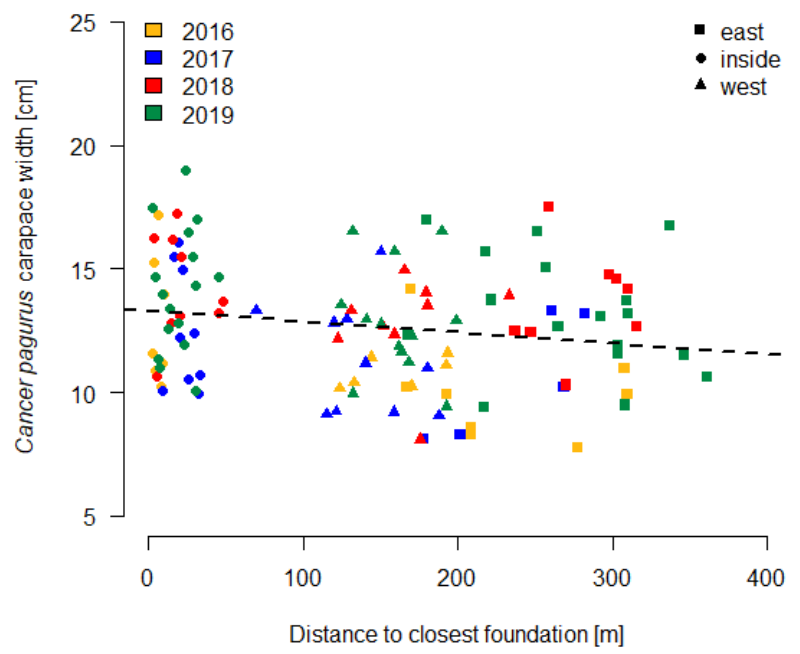

(a)

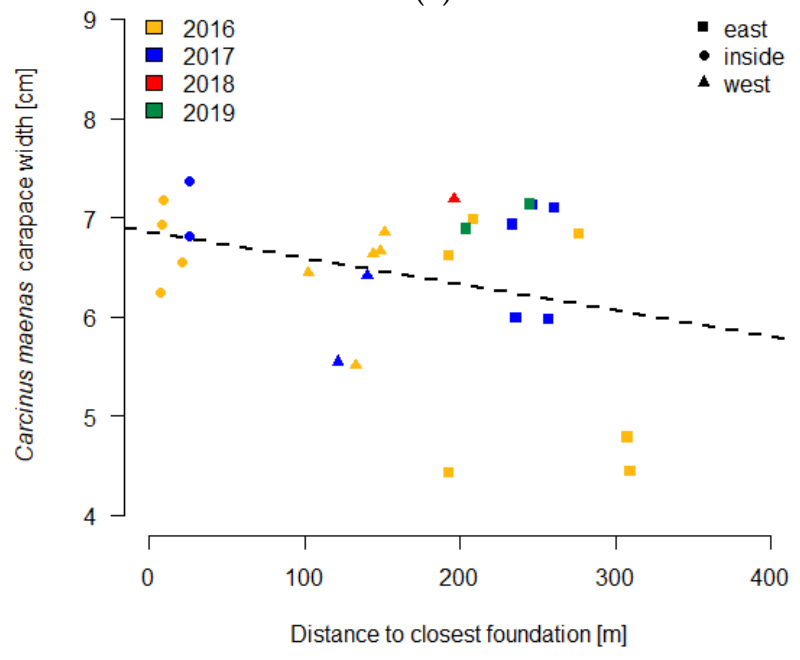

(b)

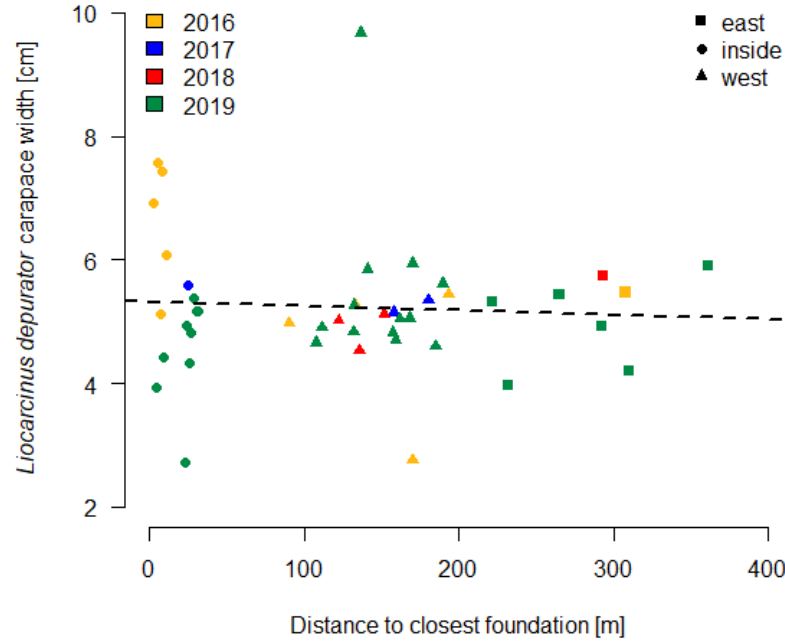

(c)

Figure 8. Average carapace width per decapod species: (a) Cancer pagurus, (b) Carcinus maenas, and (c) Liocarcinus depurator captured with large cages in 2016-2019. Black dashed line represents a pooled regression line for all years. 


\section{Discussion}

This study investigated the effects of the incidental no-take zone of a small inoperative wave power park on decapod abundance and carapace width over a period of four years. Our study generally revealed no significant differences in abundance and size of decapods in and around the park, more than 15 years after the wave power park construction. Midand long-term investigations around ORE devices are especially scarce [45], but can provide important information on the environmental impacts of such relatively new offshore technologies and are necessary to isolate their effects from inter-annual variation [57]. Samples were taken each year between late June and late July to minimize the influence of seasonal effects $[18,19]$. However, the natural inter-annual variation of numbers of individuals was high among all years for both cage types. Natural variation in numbers of individuals within a community may occur over several temporal scales from hours to decades [58], and only long-term approaches to community studies can take account of these changes. Furthermore, data from long-term studies are an essential tool in the assessment and prediction of environmental change on the community and therefore valuable for the assessment of ORE installations [59].

The number of decapods did not vary significantly with distance to ecological foundations for data pooled across all years for either the small or for the big cages. We expected to find fewer decapods with increasing distance to the ecological foundations as a result of the incidental no-take zone of the wave power park. Missing trends in decapod responses between sampling sites were confirmed for most analyses when data were analyzed for each year separately. For those years showing significant trends, the effect was small and distance to the ecological foundations explained less than $40 \%$ of the observed variance. Studies from MPAs and also ORE parks showed increased numbers of individuals inside such areas compared to outside $[18,25,60,61]$. However, several possible explanations are described below to rebut our expectations and to explain trends lacking in our study. With an area of $0.5 \mathrm{~km}^{2}$, the wave power park in our study is relatively small compared to the areal extent of most MPAs. Small MPAs seem generally less effective for their conservation benefits than larger MPAs [62]. Potentially, the size of the wave power park as a no-take zone did not meet the required minimum size to affect size and numbers of decapods.

The home range of target species could play a key role in the effect of MPA size on distribution patterns of target species around MPAs [34]. Home ranges can vary strongly across species, and the multispecies impacts of no-take zones will depend upon the range of biological characteristics and behaviors of a target species [34]. Species densities were reported to be significantly greater inside MPAs where the size of the MPA exceeded the home range of the target species. If the home range of a species exceeds the size of a protected area, possible effects, such as larger and/or more individuals inside than outside this area, could be blurred by specimens moving in and out of the area on a regular basis. Two of the three most abundant species in our study, Cancer pagurus and Carcinus maeans, showed high variation in movement rates between individuals and their ability to exceed the distance of $360 \mathrm{~m}$ within a few days $[63,64]$. Liocarcinus depurator revealed no long-term site attachment [65]. The described patterns and behaviors for the three species match with our results, where non-significant differences in decapod abundances were found among the wave power park and the areas up to $360 \mathrm{~m}$ away from it. Seasonal migration patterns, such as migrations to deeper waters during winter months, were excluded from the discussion since all investigations were performed during summer.

Another reason to explain the non-significant differences in the number of decapods with distance to the ecological foundations could be an attraction of decapod predators to the generators and ecological foundations in the park. At the study site, artificial reef effects were found, as potential predators to decapods, such as cod [13] and seals, were encountered foraging around the generators (Francisco, personal communication), as well as cage fishing by humans. An attraction of decapod predators could result in increased consumption of decapods, which would decrease their numbers and could thereby imbalance the possible positive effects of increased abundance of a no-take zone. 
Larger decapods were expected inside the wave power park due to rich epifauna on and rich infauna around the ecological foundations. Earlier studies showed an increased abundance, biomass, and diversity of infauna locally (i.e., $<1 \mathrm{~m}$ ) around the ecological foundations [15]. Mobile megafauna, such as Cancer pagurus and Gadus morhua, also showed greater species richness and numbers of individuals around the ecological foundations [13,15]. Both infauna and mobile fauna represent a food source for decapods. Areas with a rich supply of food, such as around the generators and ecological foundations, could thereby potentially contribute to a larger carapace width. The carapace width did not show significant differences with distance to the ecological foundations. However, the abundance of infauna and mobile fauna increased only within a few meters of the ecological foundations and thus accounted for only a small area of the wave power park. The effect to supply a large number of decapods with additional rich feeding grounds may be too small and local for areas close to ecological foundations to reveal an effect on carapace size or abundance at the scale of the wave power park and beyond.

One characteristic of a successful MPA is the extent to which the protection status and no-take conditions are warranted. The better the protection status is enforced, the higher the chance of the MPA having a successful outcome [66]. Around the wave power park, no commercial fishing is performed, but recreational fishing is. During all study years, several violations of recreational cage fishing inside the park occurred (personal observation by Anke Bender) and the number of undetected cases may be higher. Recreational fishing has been shown to contribute to the mortality of marine fish $[67,68]$ and might obscure or mask increased abundance and size of decapods in the park. This could be one explanation as to why decapod size and abundance showed only small, often statistically not significant trends with distance to the wave power park. Differences in fishing intensity between the years by recreational crustacean fishing around the wave power park may also have contributed to the differences in catch rates between the years.

Variation in catch rate among sampling locations was not significantly different for any of the cage types. We expected a higher catch rate from the locations outside the wave power park compared to inside, due to the incidental no-take zone of the park $[23,26,30,34-36]$, rich food sources due to higher biomass, the abundance and diversity of infauna close to the foundations [20], and enhanced mobile macrofauna on the foundations [13,15]. However, it seems that the effects may be very local and do not create a spillover to larger distances, and may not be detectable as differences in catch rate.

ORE parks are usually designed and sited with no intent to conserve biodiversity or enhance individuals, but as incidental MPAs, they still have been shown to protect organisms. The investigations of more than 80 studies have discovered that even the smallest MPA had a positive impact and the potential to bolster fisheries surrounding the MPA, as well as protect against the over-exploitation of fish stocks [69]. In the future, ORE sites will most likely continue growing to secure a sustainable energy supply. This can provide a chance to further investigate the potential of purposeful co-location of MPAs and ORE sites to enhance abundance, biomass density, and biodiversity. The Lysekil wave power park research site did not significantly influence the abundance or size of decapods in the park and up to $360 \mathrm{~m}$ around it. The results suggest that the incidental no-take zone plays a limited role as an additional benefit for the decapod community in terms of abundance and size. However, it is worth highlighting that negative effects such as decreasing abundance or smaller carapace size were non-significant. Future increase in the number and area of marine renewable energy installations may change their influence on benthos, which may warrant repetition of this study.

Author Contributions: Conceptualization, A.B., O.L. and J.S.; methodology, A.B.; software, A.B.; formal analysis, A.B. and M.M.; investigation, A.B. and O.L.; data curation, A.B. and M.M.; writingoriginal draft preparation, A.B.; writing-review and editing, A.B., O.L., M.M. and J.S.; supervision, O.L. and J.S.; visualization, A.B.; funding acquisition, J.S. All authors have read and agreed to the published version of the manuscript. 
Funding: This research was funded by the Swedish Energy Agency (grant number. 40857-1) and StandUp for Energy. The field work was financially supported by the Inez Johansson scholarship.

Institutional Review Board Statement: Not applicable.

Informed Consent Statement: Not applicable.

Data Availability Statement: Data available upon request.

Acknowledgments: The authors would like to thank Mattias Bergsman, Xin Li, Juan de Santiago Ochoa, Kevin Cestrieres, Martin Fregelius, Family Langhamer, Ivain Martinossi, Petter Lundberg, Ursula Schwarz, and Carl Kristensson for assistance in the field.

Conflicts of Interest: The authors declare no conflict of interest.

\section{References}

1. Nations, U. Sustainable Development Goals. Available online: https://sdgs.un.org/goals/goal7 (accessed on 17 July 2020$)$.

2. Lindeboom, H.J.; Kouwenhoven, H.J.; Bergman, M.J.N.N.; Bouma, S.; Brasseur, S.; Daan, R.; Fijn, R.C.; De Haan, D.; Dirksen, S.; Van Hal, R.; et al. Short-term ecological effects of an offshore wind farm in the Dutch coastal zone; a compilation. Environ. Res. Lett. 2011, 6. [CrossRef]

3. Taormina, B.; Bald, J.; Want, A.; Thouzeau, G.; Lejart, M.; Desroy, N.; Carlier, A. A review of potential impacts of submarine power cables on the marine environment: Knowledge gaps, recommendations and future directions. Renew. Sustain. Energy Rev. 2018, 96, 380-391. [CrossRef]

4. Thurstan, R.H.; Yates, K.L.; O’Leary, B.C. Compatibility of offshore energy installations with marine protected areas. In Offshore Energy and Marine Spacial Planning; Yates, K.L., Bradshaw, C.J.A., Eds.; Routledge: Abingdon, UK, 2018; pp. $214-230$.

5. Gill, A.B. Offshore renewable energy: Ecological implications of generating electricity in the coastal zone. J. Appl. Ecol. 2005, 42, 605-615. [CrossRef]

6. Copping, A.E.; Hemery, L.G. OES-Environmental 2020 State of the Science Report: Environmental Effects of Marine Renewable Energy Development Around the World; Pacific Northwest National Lab. (PNNL): Richland, WA, USA, 2020.

7. Haikonen, K. Underwater Radiated Noise from Point Absorbing Wave Energy Converters. Ph.D. Thesis, Acta Universitatis Upsaliensis, Uppsala, Sweden, 2014.

8. Williamson, B.J.; Blondel, P.; Armstrong, E.; Bell, P.; Hall, C.; Waggitt, J.J.; Scott, B. A Self-Contained Subsea Platform for Acoustic Monitoring of the Environment Around Marine Renewable Energy Devices-Field Deployments at Wave and Tidal Energy Sites in Orkney, Scotland. IEEE J. Ocean. Eng. 2015, 41, 67-81. [CrossRef]

9. Bohnsack, J.A.; Sutherland, D.L. Artificial reef research: A review with recommendations for future priorities. Bull. Mar. Sci. 1985, 37, 11-39.

10. Seaman, W.; Lindberg, W.J. Artificial Reefs. In Encyclopedia of Ocean Sciences; Academic Press: Cambridge, MA, USA, 2009; pp. 226-233. ISBN 9781840765472.

11. Serrano, A.; Rodríguez-Cabello, C.; Sánchez, F.; Velasco, F.; Olaso, I.; Punzón, A. Effects of anti-trawling artificial reefs on ecological indicators of inner shelf fish and invertebrate communities in the Cantabrian Sea (southern Bay of Biscay). J. Mar. Biol. Assoc. United Kingd. 2010, 91, 623-633. [CrossRef]

12. Komyakova, V.; Swearer, S. Contrasting patterns in habitat selection and recruitment of temperate reef fishes among natural and artificial reefs. Mar. Environ. Res. 2018, 143, 71-81. [CrossRef]

13. Langhamer, O.; Wilhelmsson, D. Colonisation of fish and crabs of wave energy foundations and the effects of manufactured holes-A field experiment. Mar. Environ. Res. 2009, 68, 151-157. [CrossRef]

14. Langhamer, O. The location of offshore wave power devices structures epifaunal assemblages. Int. J. Mar. Energy 2016, 16, 174-180. [CrossRef]

15. Bender, A.; Langhamer, O.; Sundberg, J. Colonisation of wave power foundations by mobile mega- and macrofauna-A 12 year study. Mar. Environ. Res. 2020, 161, 105053. [CrossRef]

16. Dannheim, J.; Bergström, L.; Birchenough, S.N.R.; Brzana, R.; Boon, A.R.; Coolen, J.W.P.; Dauvin, J.-C.; De Mesel, I.; Derweduwen, J.; Gill, A.B.; et al. Benthic effects of offshore renewables: Identification of knowledge gaps and urgently needed research. ICES J. Mar. Sci. 2019, 77, 1092-1108. [CrossRef]

17. Wilhelmsson, D.; Yahya, S.A.S.; Öhman, M.C. Effects of high-relief structures on cold temperate fish assemblages: A field experiment. Mar. Biol. Res. 2006, 2, 136-147. [CrossRef]

18. Reubens, J.T.; Degraer, S.; Vincx, M. The ecology of benthopelagic fishes at offshore wind farms: A synthesis of 4 years of research. Hydrobiology 2014, 727, 121-136. [CrossRef]

19. Krone, R.; Dederer, G.; Kanstinger, P.; Krämer, P.; Schneider, C.; Schmalenbach, I. Mobile demersal megafauna at common offshore wind turbine foundations in the German Bight (North Sea) two years after deployment-increased production rate of Cancer pagurus. Mar. Environ. Res. 2017, 123, 53-61. [CrossRef]

20. Langhamer, O. Effects of wave energy converters on the surrounding soft-bottom macrofauna (west coast of Sweden). Mar. Environ. Res. 2010, 69, 374-381. [CrossRef] [PubMed] 
21. Coates, D.A.; Deschutter, Y.; Vincx, M.; Vanaverbeke, J. Enrichment and shifts in macrobenthic assemblages in an offshore wind farm area in the Belgian part of the North Sea. Mar. Environ. Res. 2014, 95, 1-12. [CrossRef]

22. Miller, R.G.; Hutchison, Z.; MacLeod, A.K.; Burrows, M.; Cottier-Cook, E.; Last, K.S.; Wilson, B. Marine renewable energy development: Assessing the Benthic Footprint at multiple scales. Front. Ecol. Environ. 2013, 11, 433-440. [CrossRef]

23. Jones, E.V.; MacIntosh, D.; Stead, S.; Gray, T. How effective are MPAs in conserving crab stocks? A comparison of fisheries and conservation objectives in three coastal MPAs in Thailand. Ocean Coast. Manag. 2017, 149, 186-197. [CrossRef]

24. Moland, O.E.; Olsen, E.M.; Knutsen, H.; Garrigou, P.; Espeland, S.H.; Kleiven, A.R.; Andre, C.; Knutsen, J.A. Lobster and cod benefit from small-scale northern marine protected areas: Inference from an empirical before-after control-impact study. Proc. $R$. Soc. B Boil. Sci. 2013, 280, 20122679. [CrossRef]

25. Kleiven, P.J.N.; Espeland, S.H.; Olsen, E.M.; Abesamis, R.A.; Moland, O.E.; Kleiven, A.R. Fishing pressure impacts the abundance gradient of European lobsters across the borders of a newly established marine protected area. Proc. R. Soc. B Boil. Sci. 2019, 286, 20182455. [CrossRef]

26. Fenberg, P.B.; Caselle, J.E.; Claudet, J.; Clemence, M.; Gaines, S.D.; García-Charton, J.A.; Gonçalves, E.; Grorud-Colvert, K.; Guidetti, P.; Jenkins, S.; et al. The science of European marine reserves: Status, efficacy, and future needs. Mar. Policy 2012, 36, 1012-1021. [CrossRef]

27. Pande, A.; MacDiarmid, A.; Smith, P.; Davidson, R.; Cole, R.; Freeman, D.; Kelly, S.; Gardner, J. Marine reserves increase the abundance and size of blue cod and rock lobster. Mar. Ecol. Prog. Ser. 2008, 366, 147-158. [CrossRef]

28. Allison, G.W.; Lubchenco, J.; Carr, M.H. Marine Reserves are Necessary but not Sufficient for Marine Conservation. Ecol. Appl. 1998, 8, S79. [CrossRef]

29. Novaczek, E.; Howse, V.; Pretty, C.; Devillers, R.; Edinger, E.; Copeland, A. Limited Contribution of Small Marine Protected Areas to Regional Biodiversity: The Example of a Small Canadian No-Take MPA. Front. Mar. Sci. 2017, 4. [CrossRef]

30. Follesa, M.C.; Cuccu, D.; Cannas, R.; Cabiddu, S.; Murenu, M.; Sabatini, A.; Cau, A. Effects of marine reserve protection on spiny lobster (Palinurus elephas Fabr., 1787) in a central western Mediterranean area. Hydrobiology 2008, 606, 63-68. [CrossRef]

31. Bevacqua, D.; Melià, P.; Follesa, M.C.; De Leo, G.A.; Gatto, M.; Cau, A. Body growth and mortality of the spiny lobster Palinurus elephas within and outside a small marine protected area. Fish. Res. 2010, 106, 543-549. [CrossRef]

32. Giakoumi, S.; Scianna, C.; Plass-Johnson, J.; Micheli, F.; Grorud-Colvert, K.; Thiriet, P.; Claudet, J.; Di Carlo, G.; Di Franco, A.; Gaines, S.D.; et al. Ecological effects of full and partial protection in the crowded Mediterranean Sea: A regional meta-analysis. Sci. Rep. 2017, 7, 1-12. [CrossRef]

33. Rojo, I.; Sánchez-Meca, J.; García-Charton, J.A. Small-sized and well-enforced Marine Protected Areas provide ecological benefits for piscivorous fish populations worldwide. Mar. Environ. Res. 2019, 149, 100-110. [CrossRef]

34. Di Franco, A.; Plass-Johnson, J.G.; Di Lorenzo, M.; Meola, B.; Claudet, J.; Gaines, S.D.; García-Charton, J.A.; Giakoumi, S.; Grorud-Colvert, K.; Hackradt, C.W.; et al. Linking home ranges to protected area size: The case study of the Mediterranean Sea. Biol. Conserv. 2018, 221, 175-181. [CrossRef]

35. Claudet, J.; Pelletier, D.; Jouvenel, J.-Y.; Bachet, F.; Galzin, R. Assessing the effects of marine protected area (MPA) on a reef fish assemblage in a northwestern Mediterranean marine reserve: Identifying community-based indicators. Biol. Conserv. 2006, 130, 349-369. [CrossRef]

36. Davidson, R.; Villouta, E.; Cole, R.; Barrier, R. Effects of marine reserve protection on spiny lobster (Jasus edwardsii) abundance and size at Tonga Island Marine Reserve, New Zealand. Aquat. Conserv. Mar. Freshw. Ecosyst. 2002, 12, 213-227. [CrossRef]

37. Bayle-Sempere, J.T.; Moreno, D.; García-Charton, J.A.; Pérez-Ruzafa, A.; Sanchez-Jerez, P.; Reñones, O. Multi-scale spatial heterogeneity, habitat structure, and the effect of marine reserves on Western Mediterranean rocky reef fish assemblages. Mar. Biol. 2003, 144, 161-182. [CrossRef]

38. Murawski, S.; Rago, P.; Fogarty, M. Spillover effects from temperate marine protected areas. In Proceedings of the American Fisheries Society Symposium, Hilton Head, SC, USA, 3-5 November 2004; pp. 167-184.

39. McClanahan, T.R.; Mangi, S. Spillover of Exploitable Fishes from a Marine Park and Its Effect on the Adjacent Fishery. Ecol. Appl. 2000, 10, 1792. [CrossRef]

40. Stamoulis, K.A.; Friedlander, A.M. A seascape approach to investigating fish spillover across a marine protected area boundary in Hawai'i. Fish. Res. 2013, 144, 2-14. [CrossRef]

41. Chapman, M.R.; Kramer, D.L. Gradients in coral reef fish density and size across the Barbados Marine Reserve boundary: Effects of reserve protection and habitat characteristics. Mar. Ecol. Prog. Ser. 1999, 181, 81-96. [CrossRef]

42. Goñi, R.; Hilborn, R.; Díaz, D.; Mallol, S.; Adlerstein, S. Net contribution of spillover from a marine reserve to fishery catches. Mar. Ecol. Prog. Ser. 2010, 400, 233-243. [CrossRef]

43. Roach, M.; Cohen, M.; Forster, R.; Revill, A.S.; Johnson, M. The effects of temporary exclusion of activity due to wind farm construction on a lobster (Homarus gammarus) fishery suggests a potential management approach. ICES J. Mar. Sci. 2018, 75, 1416-1426. [CrossRef]

44. Ashley, M.; Austen, M.; Rodwell, L.; Mangi, S.C. Co-locating offshore wind farms and marine protected areas. In Offshore Energy and Marine Spacial Planning; Yates, K.L., Bradshaw, C.J.A., Eds.; Routledge: Abingdon, UK, 2018; pp. $246-259$.

45. Ashley, M.; Mangi, S.; Rodwell, L. The potential of offshore windfarms to act as marine protected areas-A systematic review of current evidence. Mar. Policy 2014, 45, 301-309. [CrossRef] 
46. Inger, R.; Attrill, M.J.; Bearhop, S.; Broderick, A.C.; Grecian, J.; Hodgson, D.J.; Mills, C.; Sheehan, E.; Votier, S.; Witt, M.; et al. Marine renewable energy: Potential benefits to biodiversity? An urgent call for research. J. Appl. Ecol. 2009, 46, 1145-1153. [CrossRef]

47. Lejerskog, E.; Gravråkmo, H.; Savin, A.; Strömstedt, E.; Tyrberg, S.; Haikonen, K.; Krishna, R.; Boström, C.; Rahm, M.; Ekström, R.; et al. Lysekil Research Site, Sweden: A Status Update. In Proceedings of the 9th European Wave and Tidal Energy Conference, Southampton, UK, 5-9 September 2011.

48. Parwal, A.; Remouit, F.; Hong, Y.; Francisco, F.; Castellucci, V.; Hai, L.; Ulvgård, L.; Li, W.; Lejerskog, E.; Baudoin, A.; et al. Wave Energy Research at Uppsala University and The Lysekil Research Site, Sweden: A Status Update. In Proceedings of the 11th European Wave and Tidal Energy Conference, Nantes, France, 6-11 September 2015; pp. 1-10.

49. Rémouit, F.; Chatzigiannakou, M.-A.; Bender, A.; Temiz, I.; Sundberg, J.; Engström, J. Deployment and Maintenance of Wave Energy Converters at the Lysekil Research Site: A Comparative Study on the Use of Divers and Remotely-Operated Vehicles. J. Mar. Sci. Eng. 2018, 6, 39. [CrossRef]

50. Cato, I.; Kjellin, B. Maringeologiska Undersökningar vid Vågkraftsanläggning Utanför Islandsberg, Bohuslän; SGU-Report 2008:10; Geological Survey of Sweden: Uppsala, Sweden, 2008; p. 17.

51. Johannesson, K. The Bare Zone of Swedish Rocky Shores: Why Is It There? Nord. Soc. Oikos 1989, 54, 77-86. [CrossRef]

52. Aberg, P. Size-Based Demography of the Seaweed Ascophyllum nodosum in Stochastic Environments. Ecology 1992, 73, $1488-1501$. [CrossRef]

53. R Core Team. R: A Language and Environment for Statistical Computing; R Foundation for Statistical Computing, R Core Team: Vienna, Austria, 2018.

54. Plaschke, S.; Bulla, M.; Cruz-López, M.; Del Ángel, S.G.; Küpper, C. Nest initiation and flooding in response to season and semi-lunar spring tides in a ground-nesting shorebird. Front. Zoöl. 2019, 16, 15. [CrossRef] [PubMed]

55. Blackwell, B.F.; Seamans, T.W.; De Vault, T.L.; Lima, S.L.; Pfeiffer, M.; Fernández-Juricic, E. Social information affects Canada goose alert and escape responses to vehicle approach: Implications for animal-vehicle collisions. PeerJ 2019, 7, e8164. [CrossRef]

56. Knief, U.; Forstmeier, W. Violating the normality assumption may be the lesser of two evils. Behav. Res. Methods 2021, 1-15. [CrossRef]

57. Wilhelmsson, D.; Langhamer, O. The Influence of Fisheries Exclusion and Addition of Hard Substrata on Fish and Crustaceans. In Marine Renewable Energy Technology and Environmental Interactions; Shields, M.A., Payne, A.I.L., Eds.; Springer: Berlin/Heidelberg, Germany, 2014; pp. 49-60. ISBN 978-94-017-8001-8.

58. Southward, A.; Hawkins, S.; Burrows, M. Seventy years' observations of changes in distribution and abundance of zooplankton and intertidal organisms in the western English Channel in relation to rising sea temperature. J. Therm. Biol. 1995, 20, 127-155. [CrossRef]

59. Magill, S.H.; Sayer, M.D.J. Seasonal and interannual variation in fish assemblages of northern temperate rocky subtidal habitats. J. Fish Biol. 2002, 61, 1198-1216. [CrossRef]

60. Coates, D.A.; Kapasakali, D.-A.; Vincx, M.; Vanaverbeke, J. Short-term effects of fishery exclusion in offshore wind farms on macrofaunal communities in the Belgian part of the North Sea. Fish. Res. 2016, 179, 131-138. [CrossRef]

61. Griffin, R.A.; Robinson, G.J.; West, A.; Gloyne-Phillips, I.T.; Unsworth, R.K.F. Assessing Fish and Motile Fauna around Offshore Windfarms Using Stereo Baited Video. PLoS ONE 2016, 11, e0149701. [CrossRef] [PubMed]

62. Edgar, G.J.; Stuart-Smith, R.D.; Willis, T.J.; Kininmonth, S.; Baker, S.C.; Banks, S.; Barrett, N.S.; Becerro, M.A.; Bernard, A.T.F.; Berkhout, J.; et al. Global conservation outcomes depend on marine protected areas with five key features. Nat. Cell Biol. 2014, 506, 216-220. [CrossRef]

63. Bolle, L.J.; Hunter, E.; Rijnsdorp, A.D.; Pastoors, M.A.; Metcalfe, J.D.; Reynolds, J.D. Do tagging experiments tell the truth? Using electronic tags to evaluate conventional tagging data. ICES J. Mar. Sci. 2005, 62, 236-246. [CrossRef]

64. Ungfors, A.; Hallbäck, H.; Nilsson, P.G. Movement of adult edible crab (Cancer pagurus L.) at the Swedish West Coast by mark-recapture and acoustic tracking. Fish. Res. 2007, 84, 345-357. [CrossRef]

65. Glass, C.W. Field and Laboratory Studies of the Behaviour of the Swimming Crab Liocarcinus depurator (Linnaeus). Ph.D. Thesis, University of Glasgow, Glasgow, Scotland, 1985.

66. Guidetti, P.; Milazzo, M.; Bussotti, S.; Molinari, A.; Murenu, M.; Pais, A.; Spanò, N.; Balzano, R.; Agardy, T.; Boero, F.; et al. Italian marine reserve effectiveness: Does enforcement matter? Biol. Conserv. 2008, 141, 699-709. [CrossRef]

67. Sande, H. Recreational Fisheries-Characterization, Quantification and Biological Impact on Natural Resources; Aqua Introductory Research Essay 2020: Swedish University of Agricultural Sciences, Department of Aquatic Resources; Drott-ningholm Lysekil: Öregrund, Sweden, 2020; p. 46.

68. Radford, Z.; Hyder, K.; Zarauz, L.; Mugerza, E.; Ferter, K.; Prellezo, R.; Strehlow, H.V.; Townhill, B.; Lewin, W.-C.; Weltersbach, M.S. The impact of marine recreational fishing on key fish stocks in European waters. PLoS ONE 2018, 13, e0201666. [CrossRef] [PubMed]

69. Halpern, B.S. The impact of marine reserves: Do reserves work and does reserve size matter? Ecol. Appl. 2003, 13, 117-137. [CrossRef] 